Int. J. Odontostomat., 6(3):255-262, 2012.

\title{
Treatment and Complications of Orbito-zygomatic Fractures
}

\author{
Tratamiento y Complicaciones de las Fracturas Órbito-cigomáticas
}

\author{
Paulo Alceu Kiemle Trindade*; Eduardo Hochulli Vieira**; Marisa Aparecida Cabrini Gabrielli"; \\ Mario Francisco Real Gabrielli ${ }^{* * *}$ \& Valfrido Antonio Pereira-Filho ${ }^{\star \star * *}$
}

TRINDADE, P. A. K.; VIEIRA, E. H.; GABRIELLI, M. A. C.; GABRIELLI, M. F. R. \& PEREIRA-FILHO, V. A. Treatment and complications of orbito-zygomatic fractures. Int. J. Odontostomat., 6(3):255-262, 2012.

ABSTRACT: The aim of the present study was to analyze the etiology, type and treatment employed in the orbitozygomatic fractures (OZ). Also, postoperative complications are described and correlated with the type of treatment used. Fifty patients with OZ fractures were evaluated. Orbital fractures in which the zygomatic bone was not involved were excluded. Epidemiologic data and characteristics of treatment such as the type of material used for osteosynthesis, number of anatomical sites on which rigid internal fixation (RIF) was applied, surgical approaches and associated complications were recorded. The main causes of trauma were motorcycle and bicycle accidents, constituting $52 \%$ of the sample. The osteosynthesis system used was the $2.0 \mathrm{~mm}$, except in four patients in whom the $1.5 \mathrm{~mm}$ system was used for fixation at the infra-orbital rim. A total of $18 \%$ of the patients required reconstruction of the internal orbit and in all cases titanium mesh was used. $46 \%$ of the patients received RIF in three anatomical sites, most in the fronto-zygomatic suture, infra-orbital rim and zygomatic-maxillary buttress. The most frequent complication was paresthesia of the infra-orbital nerve (34 patients, 68\%). Other findings were also discussed with the intent of better understanding the treatment of the OZ fractures.

KEY WORDS: zygoma, orbit, facial fractures.

\section{INTRODUCTION}

Orbito-zygomatic fractures represent a type of maxillofacial injury that happens very often due to the prominent position that the zygomatic bone occupies in the facial skeleton. The incidence, etiology and predilection for sex and age of trauma itself depends on social, economic and political status of the population studied and can vary greatly depending on sample's location (Ellis et al., 1985; Gomes et al., 2006).

Treatment of the OZ fractures seeks to restore the function of the orbital complex as well as the facial esthetics of the patient. The eye function depends on the correct three-dimensional positioning of the bones that make up the orbit. When an OZ fracture happens, there is usually an increase in orbital volume by the displacement of the fractured bones. The anteroposterior displacement of the globe, characterized as enophthalmos, and the vertical displacement of the orbital contents that are not treated can generate an unequal pupil level inducing binocular diplopia. This condition may initially be masked by tissue swelling. Moreover, an unidentified defect in the orbital floor can cause an impairment of eye movements by the soft tissue entrapment into the bone fragments. Besides, injury to the extraocular muscles, intraorbital or muscle hemorrhage and edema can also cause an impairment of eye movements or even a diminished visual acuity. Direct trauma to the eyeball

* DDS, Oral and Maxillofacial Surgery Resident, Department of Oral and Maxillofacial Surgery and Periodontology, Ribeirão Preto School of Dentistry, University of São Paulo-USP, Ribeirão Preto-SP, Brazil.

* DDS, PhD, Associate Professor, Department of Diagnosis and Surgery, Division of Oral and Maxillofacial Surgery, Araraquara School of Dentistry, São Paulo State University-UNESP, Araraquara-SP, Brazil.

*** DDS, PhD, Chairman Professor, Department of Diagnosis and Surgery, Division of Oral and Maxillofacial Surgery, Araraquara School of Dentistry, São Paulo State University-UNESP, Araraquara-SP, Brazil.

${ }^{* * * *}$ DDS, PhD, Assistant Professor, Department of Diagnosis and Surgery, Division of Oral and Maxillofacial Surgery, Araraquara School of Dentistry, São Paulo State University-UNESP, Araraquara-SP, Brazil. 
may be related to the $\mathrm{OZ}$ fractures and can induce a series of ophthalmic complications. Gross visual acuity and the ocular structures must be examined by the surgeon and referral to the ophthalmologist must always be considered (Ellis, 1991; Manolidis et al., 2002; Ellis \& Tan, 2003; Bailey \& Goldwasser, 2004; Wilson \& Ellis, 2006; Sleep et al., 2007; Barry et al., 2008; Scolozzi et al., 2009; Tabrizi et al., 2010; Holmes, 2011).

Regarding the stomathognatic system, bite force can also be affected when a zygomatic fracture happens due to the fact that the masseter muscle originates on the zygomatic arch, which may be affected (Dal Santo et al., 1992). The displacement of the fractured zygomatic arch may also limit the mouth opening due to mechanical impairment of the coronoid process of the mandible (Ellis; Bailey \& Goldwasser).

Many kinds of surgical approaches can be used and each of them has its advantages and disadvantages. Amount of exposure, skin scars and technical difficulty must be considered. Functional and aesthetics defects of the lower eyelid may happen when the transconjunctiva and subciliary approaches are needed (Wilson \& Ellis; Ridgway et al., 2009). The bicoronal approach also may cause sensorial and motor disturbance (Al-Kayat \& Bramley, 1979; Zhang et al., 2006; do Egito Vasconcelos et al., 2007).

Paresthesia of the ION is often present and may happen due the fracture itself or surgical trauma (Taicher et al., 1993; Vriens \& Moos, 1995; Vriens et al., 1998).

The adequacy of reduction, stability of fixation and lower rates of post-operative complications are linked to the ability of the surgeon, type of osteosythesis material and surgical techniques used (Ellis et al.; Ellis \& Kittidumkerng, 1996; Markowitz \& Manson, 1998; Rohner et al., 2002; Gomes et al.; Olate et al., 2010). Therefore, it is necessary to correlate a standard of treatment of the $\mathrm{OZ}$ fractures with a certain success rate in a population in particular to improve the trauma patient care in general. Also, epidemiological findings of a particular type of trauma are very important in establishing preventive measures for safety.

This study makes an analysis of the etiology, type and treatment employed for OZ fractures and correlates postoperative complications with the type of treatment used.

\section{MATERIAL AND METHOD}

Fifty patients with $\mathrm{OZ}$ fractures were evaluated. Data regarding the etiology, age group and sex distribution of trauma were recorded as well as the characteristics of treatment such as type of osteosynthesis material and the anatomical location at which they were installed.

As no previous published classifications of the $\mathrm{OZ}$ fractures were used in this study, it was determined instead, the number of anatomical sites on which RIF were used in order to establish a pattern of fixation. The anatomical landmarks used for this purpose were the zygomatico-maxillary buttress (ZMB), infra-orbital rim (IOR), fronto-zygomatic suture (FZS), zygomatic arch (ZA) and the internal orbit.

Also, surgical approaches and associated postoperative complications as well as the concomitant facial fractures were evaluated. Patients had at least 3 months of follow up. All data was gathered and expressed as simple percentage in tables and graphics. The study excluded patients with orbital fractures in which the zygomatic bone was not involved.

\section{RESULTS}

Most OZ fractures occurred in men aged between 21 and 30 years (38\%) (Fig.1). The main etiology was two-wheel vehicle accidents, constituting a total of $52 \%$ of the sample [motorcycle crash (32\%) and bicycle fall $(20 \%)$ ], followed by assault (18\%), fall from own height (10\%), among others (Fig. 2). Bilateral fractures of orbito-zygomatic complex were found in only 2 patients $(4 \%)$, whereas unilateral fractures were present in 48 patients (96\%), 25 (50\%) on the left side and $23(46 \%)$ on the right side.

As surgical treatment, the most common pattern was the RIF at the fronto-zygomatic suture, infraorbital arch and zygomatic-maxillary buttress in $44 \%$ of the patients.

A total of $18 \%$ of the patients required reconstruction of the internal orbit and in all cases titanium mesh was used. Only in one patient RIF was not used after reducing the fracture. Other patterns of fixation at different anatomical sites were used and are expressed in Table I. 


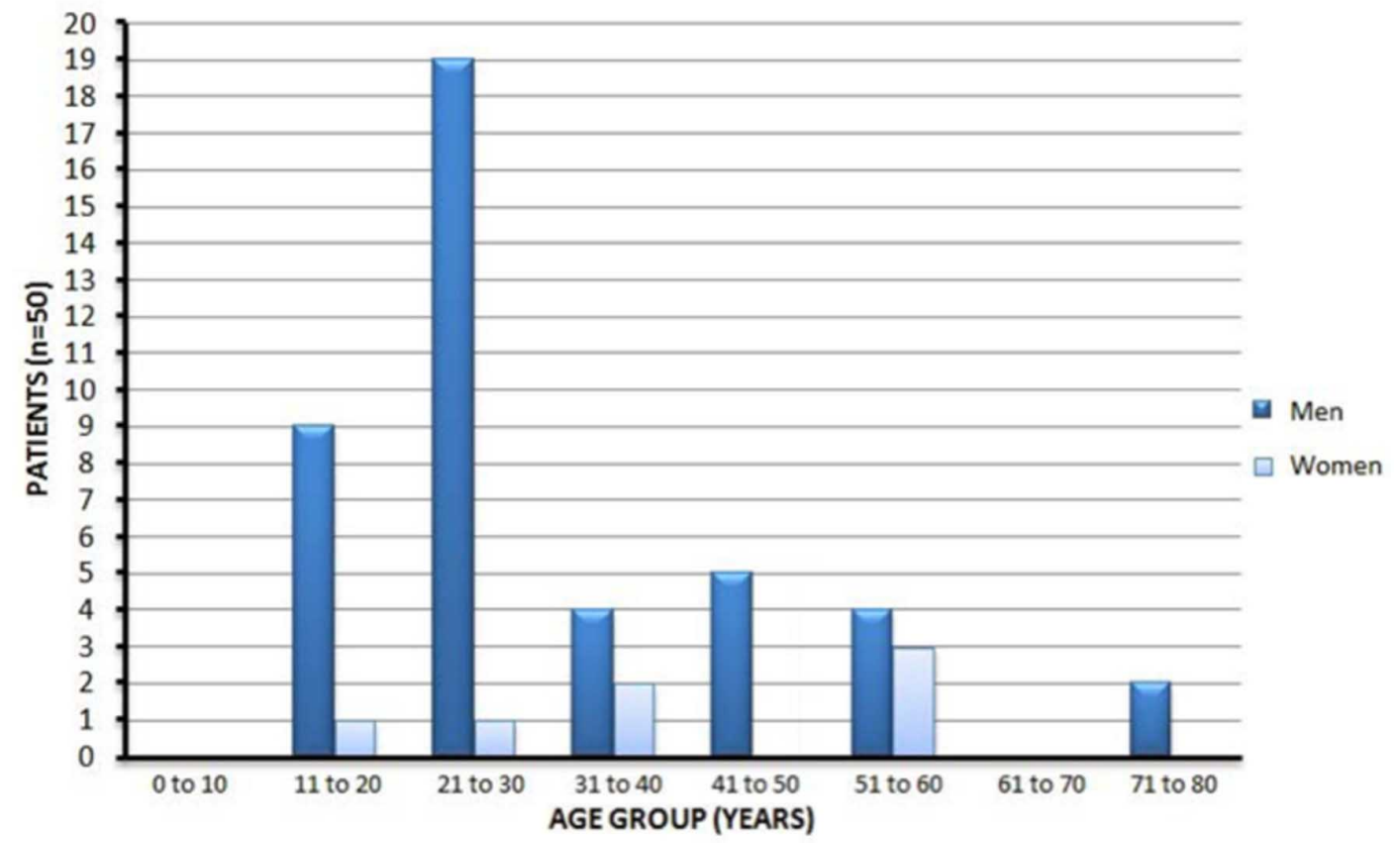

Fig. 1. Distribution of age and sex of the OZ fractures.

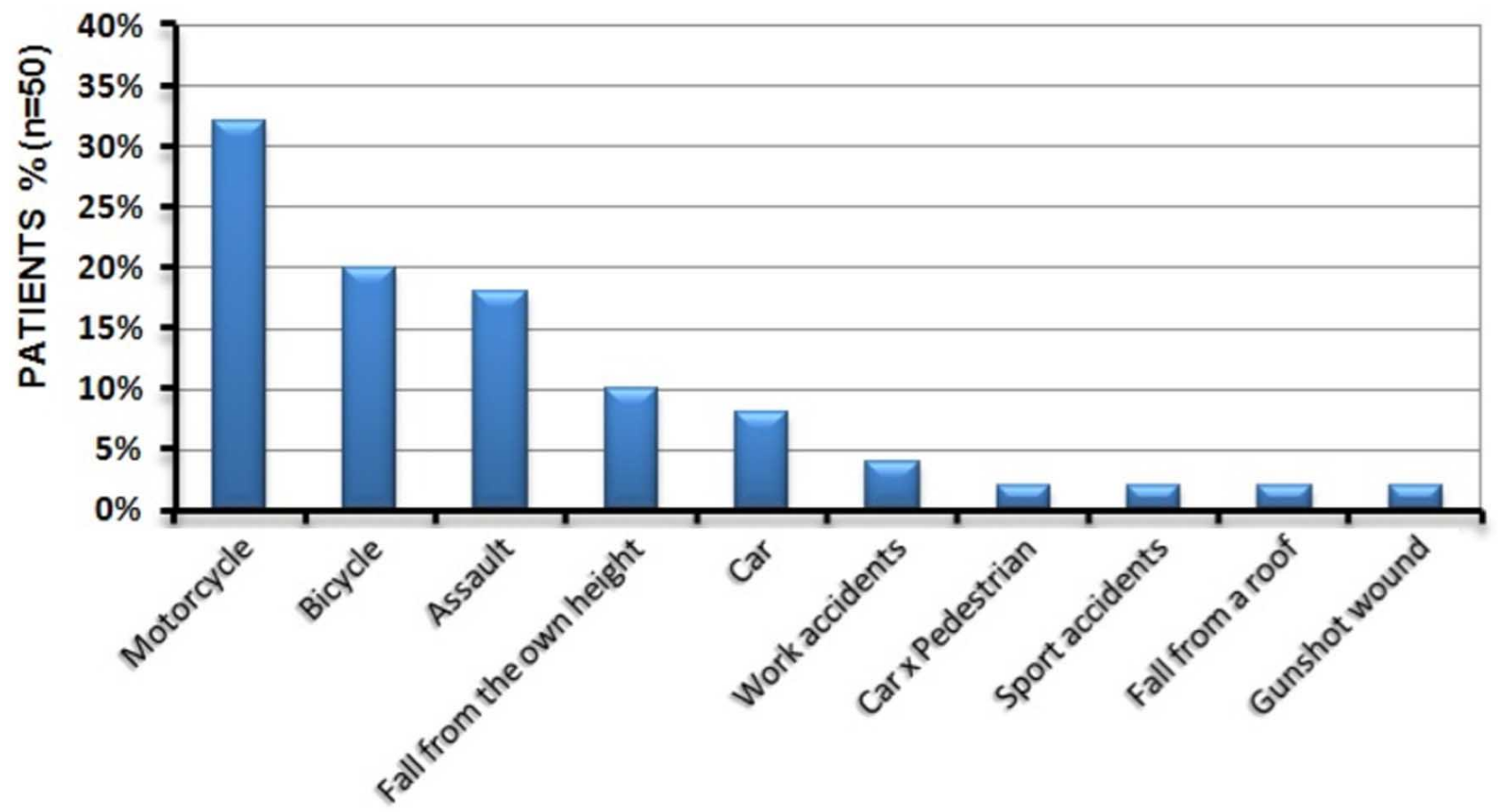

Fig. 2. Etiology of trauma.

Facial fractures most commonly associated with the OZ fractures were LeFort II (14\%) and nasal fractures $(10 \%)$. However, several other types of facial fractures were found concomitant (Fig. 3).

The most frequent complication was paresthesia of the ION (34 patients, $68 \%$ of the sample). Complications involving the eye function were found in 7 patients.Aesthetic-functional defects of the lower eyelid were found in 4 patients. Transient motor deficit of the facial nerve was found in 3 patients who underwent bicoronal approach with preauricular extension (Fig. 4, Tables II and III). 
TRINDADE, P. A. K.; VIEIRA, E. H.; GABRIELLI, M. A. C.; GABRIELLI, M. F. R. \& PEREIRA-FILHO, V. A. Treatment and complications of orbito-zygomatic fractures. Int. J. Odontostomat., 6(3):255-262, 2012.

Table I. Surgical treatment and anatomical sites where RIF was used.

\begin{tabular}{lccc}
\hline & Anatomical sites & $\mathbf{n}$ & \% \\
\hline Without RIF & Reduction without RIF & 1 & 2 \\
RIF at 1 site & ZMB & 5 & 10 \\
RIF at 2 sites & FZS + IOR & 1 & \\
& FZS + ZMB & 3 & 18 \\
RIF at 3 sites & ZMB + IOR & 5 & \\
RIF at 4 sites & ZMB + FZS + IOR & 22 & 46 \\
& ZMB + FZS + ZA & 1 & \\
& ZMB + FZS + IOR + ZA & 3 & 6 \\
Need for internal orbit reconstruction & IOR + OF & 1 & \\
& ZMB + FZS + IOR + LOW & 1 & \\
& ZMB + IOR + ZA + OF + LOW & 1 & \\
& ZMB + FZS + OF & 2 & \\
& ZMB + FZS + IOR + OF & 1 & \\
\hline
\end{tabular}

*Legend: RIF= Rigid Internal Fixation, ZMB= Zygomatic Maxillary Buttress, FZS= Fronto Zygomatic Suture, IOR= Infra Orbital Rim, ZA= Zygomatic Arch, OF= Orbital Floor, LOW= Lateral Orbital Wall.

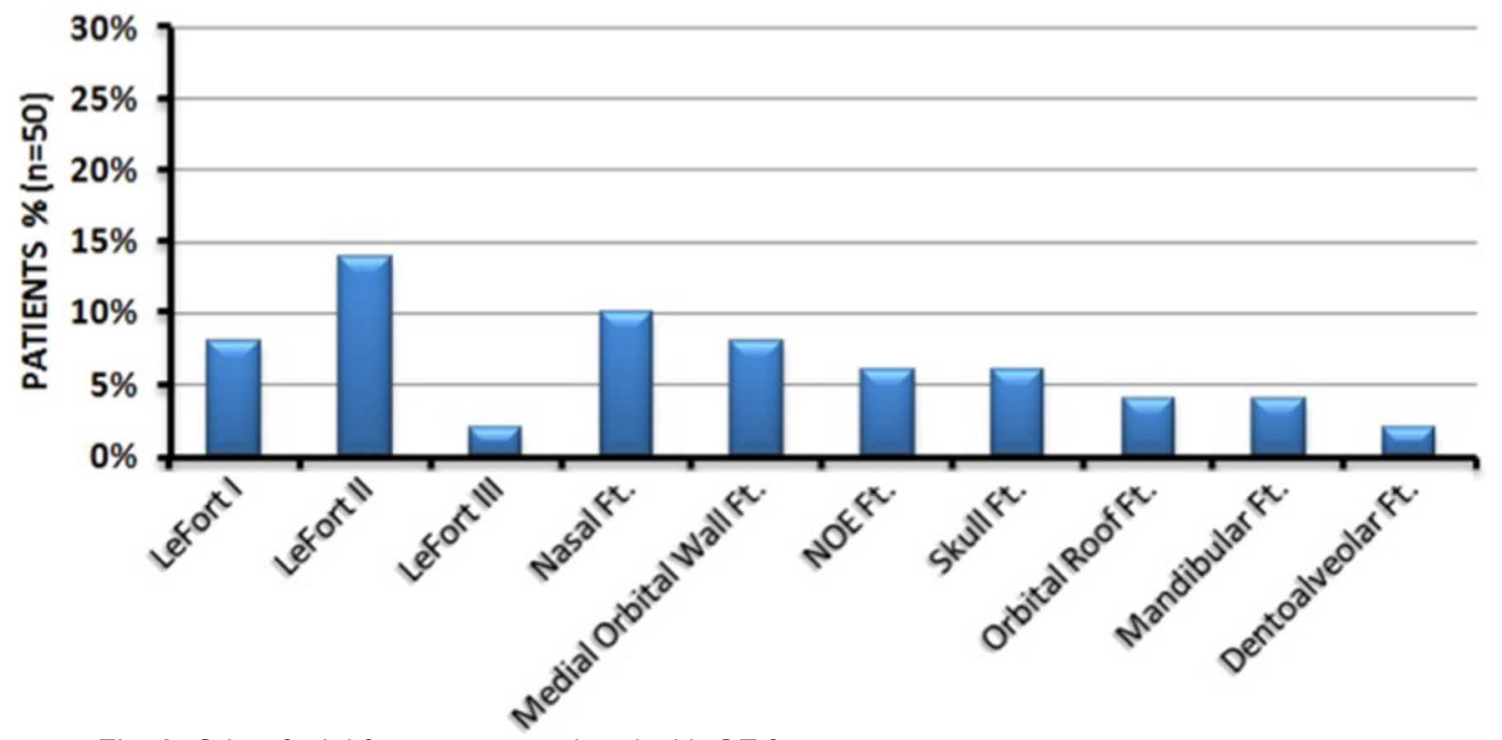

Fig. 3. Other facial fractures associated with $\mathrm{OZ}$ fractures.

Table II. Complications related to the bicoronal approach with or without preauricular extension.

\begin{tabular}{lcc}
\hline & $\begin{array}{c}\text { Bicoronal approach } \\
\text { with pre auricular }\end{array}$ & $\begin{array}{c}\text { Bicoronal approach without } \\
\text { preauricular extension }\end{array}$ \\
\hline Motor deficit of the facial nerve & 3 & 0 \\
Total & 7 & 3 \\
\hline
\end{tabular}




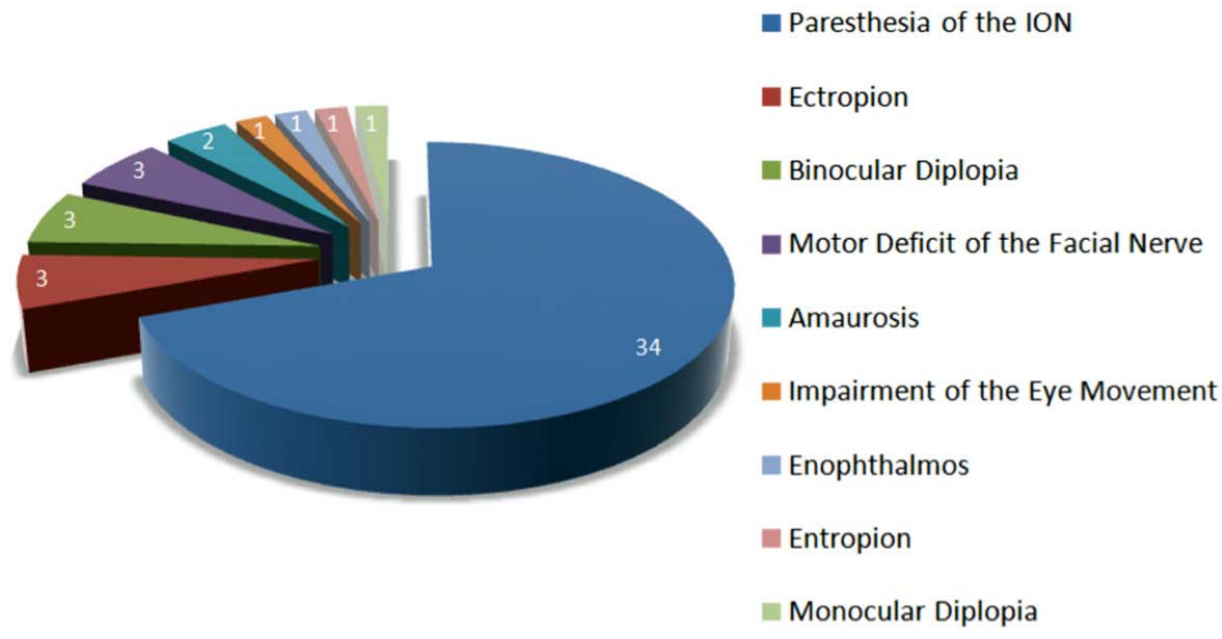

Fig. 4. Complications associated with $\mathrm{OZ}$ fractures.

Table III. Complications related to the surgical approaches to the infraorbital rim.

\begin{tabular}{lcccc}
\hline & \multicolumn{4}{c}{ Surgical approaches to the infraorbital rim } \\
\cline { 2 - 5 } & $\begin{array}{l}\text { Subciliary without } \\
\text { lateral extension }\end{array}$ & $\begin{array}{c}\text { Subcialiry with } \\
\text { lateral }\end{array}$ & $\begin{array}{c}\text { Tranconjuntival } \\
\text { without }\end{array}$ & $\begin{array}{c}\text { Tranconjuntival } \\
\text { with }\end{array}$ \\
\hline Entropion & --- & --- & $1^{*}$ & -- \\
Ectropion & 2 & 1 & --- & -- \\
Total & 23 & 2 & 6 & 1 \\
\hline
\end{tabular}

*Laceration of the lower eyelid during surgery.

\section{DISCUSSION}

Although there is plenty of classifications and patterns for the OZ fractures, those were not used in this study due to lack of data from the medical charts to accurately describe each type of fracture according to a certain classification. Instead, it was determined the anatomical sites that RIF was used and which osteosynthesis system was installed on it in order to determine a pattern of treatment, correlating it with the other variants of the study such as etiology (trauma of high or low energy), comminution, degree of displacement of fractures, complication rates and other associated facial fracture.

Forty-six \% of patients received RIF at 3 anatomical sites. Among them, 22 of 23 patients received RIF at the fronto-zygomatic suture, infra-orbital rim and at thezygomatic-maxillary buttress. Such pattern was the most used for the treatment of the ZMC fractures in this sample and it seemed to be effective regarding three dimensional stability since none of the patients had any kind of displacement or gross asymmetry after surgery that was noticed in the postoperative clinical examination.

It was not the aim of this study to establish if a pattern of 4 or 3 points fixation is better than a 2 points or 1 point of fixation of the $\mathrm{OZ}$ fractures. Each kind of fracture has its own characteristics and the location or the number of miniplates used, as well as the extent of open reduction, will depend on where the fracture line runs, amount of displacement and comminution. If the fracture can be stabilized with only 1 or 2 points of fixation there is no need to go for another point. In the same manner, whenever a fracture is reduced and fixated at one point and still seems unstable to the surgeon or if the other points of reference are not 
properly aligned, another point must be exposed to confirm alignment and to provide fixation (Ellis \& Kittidumkerng; Markowitz \& Manson).

Post-operative stability may also be related with the kind of osteosynthesis material used (Ellis et al.; Ellis \& Kittidumkerng; Markowitz \& Manson; Rohner et al.). For the reconstruction of the external bone frame the $2.0 \mathrm{~mm}$ osteosynthesis system was used except in 4 patients that had their infra-orbital rim fixated with the $1.5 \mathrm{~mm}$ system.

Comminution and amount of displacement must be considered for the choice of the osteosynthesis material. If there is any doubt about which kind of miniplate must be used a rigid one must be placed. The 2.0 osteosynthesis system was the most used in this study. Even at the IOR, no complaints were recorded about sensibility on palpation at the miniplate's location in this particular position where the skin is thinner. Nevertheless, we recommend the use of the 1.5 system at the IOR if available, because thicker miniplates can eventually cause discomfort to the patient.

The need for internal orbital reconstruction was usually linked to high-energy trauma, although blow out fractures can also happen due simple blunt trauma to the orbital complex. (Manolidis et al.; Ellis \& Tan; Sleep et al.; Scolozzi et al.; Tabrizi et al.; Holmes).

For the reconstruction of the orbital floor, medial and lateral wall, only titanium mesh was used. Late enophthalmos was found in only one patient in whom the orbital floor was fractured and was not reconstructed at the first procedure. Complications involving the eye function as well as mono and binocular diplopia and amaurosis were associated with high-energy trauma in which there was always a need for RIF in more than three anatomical points.

In a total of 32 approaches to the infra-orbital rim (subciliary with/without lateral extension or transconjunctival with/without lateral canthotomy), 4 caused a functional-aesthetic defect in the lower eyelid (ectropion or entropion). It is not possible to correlate a complication rate for each approach to the infra-orbital rim, because the sample in this study is too small. The surgeon's experience however, seems to be imperative for a lower rate of complications.
A transient motor deficit of the facial nerve was found in 3 patients, in a total of 7 , who underwent bicoronal approach with preauricular extension. The need for using the bicoronal approach, particularly with preauricular extension, was linked with reconstruction by open reduction and fixation of comminuted zygomatic arch and extensive orbital exploration.

However, the most common postoperative sequel of the $\mathrm{OZ}$ fractures was paresthesia of the ION. This condition can occur during elevation of the buccal maxillary flap, but it most often occurs as a result of the fracture line that usually runs through the infra-orbital foramen or secondary to a blunt trauma (Ellis; Vriens \& Moos; Vriens et al.; Bailey \& Goldwasser; Taicher et al. The present study found that 34 patients, $68 \%$ of the sample, showed varying degrees of numbness of the ION. In the most cases this was a transient condition.

\section{CONCLUSION}

In summary, this study has shown that the predilection of the $\mathrm{OZ}$ fractures was much higher for men than women ( $86 \%$ men and $14 \%$ women) being the age group of 21 to 30 years old was the most affected. Motorcycle and bicycle accidents were the major etiology of trauma and together constituted 52\% of the sample. The most common pattern of surgical treatment was the RIF at the fronto-zygomatic suture, infraorbital arch and zygomatic-maxillary buttress in $44 \%$ of the patients. Need for internal orbit reconstruction and zygomatic arch fixation seemed to be linked with high energy trauma. Orbital reconstruction was always done with titanium mesh and the 2.0 system was the most used.

Complications inherent to the surgical act were low and most linked with nerve damage at performing the bicoronal approach with preauricular extension or skin repair defects when performing the subciliary and transconjunctival approach. We have not considered paresthesia of the ION as a complication of the surgical act but the trauma itself because it was present before surgery. In fact, the treatment of $\mathrm{OZ}$ fractures was considered successfully since no loss of reduction of the fractured zygomatic bone or gross facial asymmetry were recorded and the rate of complications linked to the surgical act itself was quite low. 
TRINDADE, P. A. K.; VIEIRA, E. H.; GABRIELLI, M. A. C.; GABRIELLI, M. F. R. \& PEREIRA-FILHO, V. A. Tratamiento y complicaciones de las fracturas órbito-cigomáticas. Int. J. Odontostomat., 6(3):255-262, 2012.

RESUMEN: El objetivo del presente estudio fue analizar la etiología, tipo y tratamiento empleado en las fracturas órbito-cigomáticas $(\mathrm{OC})$. Además, se describen y correlacionan las complicaciones postoperatorias con el tipo de tratamiento utilizado. Cincuenta pacientes con fracturas OC fueron evaluados. Las fracturas orbitarias en la que el hueso cigomático no participó fueron excluidas. Los datos epidemiológicos y las características de tratamiento, tales como el tipo de material utilizado para la osteosíntesis, número de sitios anatómicos en los que se aplicó la fijación interna rígida (FIR), enfoques quirúrgicos y complicaciones asociadas fueron registrados. Las principales causas de los traumas fueron accidentes de bicicleta y motocicleta, constituyendo el $52 \%$ de la muestra. El sistema de osteosíntesis utilizado fue de 2,0 mm, excepto en cuatro pacientes en los que se utilizó el sistema de 1,5 mm para la fijación en el borde infraorbitario. El 18\% de los pacientes requirieron reconstrucción de la órbita interna y en todos los casos se utilizó malla de titanio. El 46\% de los pacientes recibió FIR en tres sitios anatómicos, la mayoría en la sutura fronto-cigomático, borde infraorbitario y pilar cigomato-maxilar. La complicación más frecuente fue parestesia del nervio infraorbitario (34 pacientes, 68\%). Otros hallazgos fueron discutidos con la intención de comprender mejor el tratamiento de las fracturas OC.

PALABRAS CLAVE: hueso cigomático, órbita, fracturas faciales.

\section{REFERENCES}

Al-Kayat, A. \& Bramley, P. A modified pre-auricular approach to the temporomandibular joint and malar arch. Br. J. Oral Maxillofac. Surg., 17(2):91$103,1979$.

Bailey, J. S. \& Goldwasser, M. S. Management of zygomatic complex fractures. In: Miloro M. (ed.), Peterson's principles of oral and maxillofacial surgery. 2nd ed. Hamilton, Decker, 2004. pp.44562.

Barry, C.; Coyle, M.; Idrees, Z.; Dwyer, M. H. \& Kearns, G. Ocular findings in patients with orbitozygomatic complex fractures: a retrospective study. J. Oral Maxillofac. Surg., 66(5):888-92, 2008.

Dal Santo, F.; Ellis, E. 3rd \& Throckmorton, G. S. The effects of zygomatic complex fracture on masseteric muscle force. J. Oral Maxillofac. Surg., 50(8):7919, 1992.

do Egito Vasconcelos, B. C.; Bessa-Nogueira, R. V. \& da Silva, L. C. Prospective study of facial nerve function after surgical procedures for the treatment of temporomandibular pathology. J. Oral Maxillofac. Surg., 65(5):972-8, 2007.

Ellis, E. Fractures of the zygomatic complex and arch. In: Fonseca, R. J. \& Walker, R. V. (Eds.). Oral and maxillofacial trauma. Philadelphia, Saunders, 1991. pp.435-51.
Ellis, E. 3rd; El-Alttar, A. \& Moos, K.F. An analysis of 2,067 cases of zygomatico-orbital fracture. J. Oral Maxillofac. Surg., 43:417-28,1985.

Ellis, E. 3rd \& Kittidumkerng, W. Analysis of treatment for isolated zygomaticomaxillary complex fractures. J. Oral Maxillofac. Surg., 54(4):386-400,1996.

Ellis, E. 3rd \& Tan, Y. Assessment of internal orbital reconstructions for pure blowout fractures: cranial bone grafts versus titanium mesh. J. Oral Maxillofac. Surg., 61(4):442-53,2003.

Gomes, P. P.; Passeri, L. A. \& Barbosa, J. R. A 5-year retrospective study of zygomatico-orbital complex and zygomatic arch fractures in São Paulo State. J. Oral Maxillofac. Surg., 64(1):63-7, 2006.

Holmes, S. Reoperative orbital trauma: management of posttraumatic enophthalmos and aberrant eye position. Oral Maxillofac. Surg. Clin. North Am., 23(1):17-29, 2011.

Manolidis, S.; Weeks, B. H.; Kirby, M.; Scarlett, M. \& Hollier, L. Classification and surgical management of orbital fractures: experience with 111 orbital reconstructions. J. Craniofac. Surg., 13(6):726-38, 2002.

Markowitz, B. \& Manson, P. N. Zygomatic complex fracture. In: Prein, J. (Ed.). Manual of internal fixation 
in the cranio-facial skeleton: techniques recommended by the AO/ASIF Maxillofacial Group. Heidelberg, Springer, 1998. pp.133-8.

Olate, S.; Lima, S. M. Jr.; Sawazaki, R.; Moreira, R. W. \& de Moraes, M. Surgical approaches and fixation patterns in zygomatic complex fractures. J. Craniofac. Surg., 21(4):1213-7, 2010.

Ridgway, E. B.; Chen, C. \& Lee, B. T. Acquired entropion associated with the transconjunctival incision for facial fracture management. J. Craniofac. Surg., 20(5):1412-5, 2009.

Rohner, D.; Tay, A.; Meng, C. S.; Hutmacher, D. W. \& Hammer, B. The sphenozygomatic suture as a key site for osteosynthesis of the orbitozygomatic complex in panfacial fractures: a biomechanical study in human cadavers based on clinical practice. Plast. Reconstr. Surg., 110(6):1463-75, 2002.

Scolozzi, P.; Momjian, A.; Heuberger, J.; Andersen, E.; Broome, M.; Terzic, A. \& Jaques, B. Accuracy and predictability in use of $\mathrm{AO}$ three-dimensionally preformed titanium mesh plates for posttraumatic orbital reconstruction: a pilot study. J. Craniofac. Surg., 20(4):1108-13, 2009.

Sleep, T. J.; Evans, B. T. \& Webb, A. A. Resolution of diplopia after repair of the deep orbit. Br. J. Oral Maxillofac. Surg., 45(3):190-6, 2007.

Tabrizi, R.; Ozkan, T. B.; Mohammadinejad, C. \& Minaee, N. Orbital Floor Reconstruction. J. Craniofac. Surg., 21(4):1142-6, 2010.

Taicher, S.; Ardekian, L.; Samet, N.; Shoshani, Y. \& Kafle, I. Recovery of the infraorbital nerve after zygomatic complex fractures: a preliminary study of different treatment methods. Int. J. Oral Maxillofac. Surg., 22(6):339-41,1993.

Vriens, J. P. \& Moos, K. F. Morbidity of the infraorbital nerve following orbitozygomatic complex fractures. J. Craniomaxillofac. Surg., 23(6):363-8, 1995.

Vriens, J. P.; van der Glas, H. W.; Moos, K. F. \& Koole, R. Infraorbital nerve function following treatment of orbitozygomatic complex fractures: a multitest approach. Int. J. Oral Maxillofac. Surg., 27(1):2732, 1998.
Wilson, S. \& Ellis, E. 3rd. Surgical approaches to the infraorbital rim and orbital floor: the case for the subtarsal approach. J. Oral Maxillofac. Surg., 64(1):104-7, 2006.

Zhang, Q. B.; Dong, Y. J.; Li, Z. B. \& Zhao, J. H. Coronal incision for treating zygomatic complex fractures. J. Craniomaxillofac. Surg., 34(3):182-5, 2006.

Correspondence to:

Paulo Alceu Kiemle Trindade

Rua Bernardino de Campos 435, AP 404, Centro

CEP 14015130

Ribeirão Preto-SP

BRASIL

Email:paulotrin@uol.com.br

Received: 28-05-2012

Accepted: 03-08-2012 